\title{
The Acute Effect of Erythropoietin on Mean Platelet Volume Levels during Hypoxia Reoxygenation Injury in Rats
}

\section{Farelerde Hipoksi Reoksijenasyon Hasarında Eritropoietinin Ortalama Trombosit Hacim Düzeyleri Üzerindeki Akut Etkisi}

\author{
Constantinos Tsompos, Constantinos Panoulis*, Konstantinos Toutouzas**, \\ Aggeliki Triantafyllou***, George Zografos**, Apostolos Papalois**** \\ Mesologi County Hospital, Clinic of Obstetrics and Gynecology, Mesologi, Greece \\ ${ }^{*}$ Aretaieion Hospital, Clinic of Obstetrics and Gynecology, Athens, Greece \\ **Ippokrateion Hospital, Clinic of Surgery, Athens, Greece \\ ${ }^{* * *}$ Athens University Faculty of Medicine, Department of Biologic Chemistry, Athens, Greece \\ $* * * *$ ELPEN Pharmaceuticals, S.A. Inc., Co, Experimental Research Centre, Pikermi, Greece
}

\section{Abstract}

Aim: This biomedical study tested the effect of erythropoietin (Epo) in rat model, especially in a hypoxia-reoxygenation one. The trend of this factor was evaluated hematologically using serum mean platelets volume (MPV) values.

Methods: Forty rats with a mean mass $247.7 \mathrm{~g}$ were used. MPV values were evaluated at $60 \mathrm{~min}$ (for groups $A$ and C) and at 120 min (for groups $B$ and $D$ ) of reoxygenation. Epo was provided only in groups $C$ and D.

Results: Epo administration non-significantly lowered the MPV levels by $0.12 \%+2.13 \%$ ( $p=0.9513)$. Reoxygenation time non-significantly augmented the MPV levels by $1.37 \%+2.11 \%(p=0.4873)$. However, Epo administration together with reoxygenation time non-significantly reduced the MPV levels by $0.27 \%+0.92 \%$ ( $p=0.7585)$.

Conclusion: Epo administration had a non-significant short-time decline effect on MPV levels.

Keywords: Hypoxia, erythropoietin, reoxygenation, mean platelets volume
Giriş: Bu deneysel çalışmada, eritropoietinin (Epo) etkisi fare modelinde, özellikle bir hipoksi-reoksijenasyon protokolü dahilinde incelendi. Bu molekülün etkisi, kan ortalama trombosit düzeyleri (MPV) kullanılarak hematolojik olarak incelendi.

Yöntemler: Ortalama 247,7 gr ağırlığa sahip 40 adet fare çalışmada kullanıldı. MPV düzeyleri 60 dakikalık (A ve C grupları) ve 120 dakikalık (B ve D grupları) reoksijenasyonlarla ölçüldü. Sadece $C$ ve $D$ gruplarına Epo verildi.

Bulgular: Epo uygulanması MPV düzeylerini kayda değer olmayan bir şekilde $\% 0,12 \pm \% 2,13$ ( $p=0,9513$ ) oranında yükseltirken reoksijenasyon

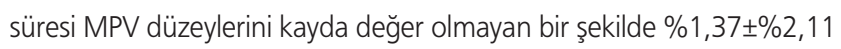
$(p=0,4873)$ arttırdı. Ancak, Epo verilmesi ile reoksijenasyon süresi bir araya geldiğinde MPV değerlerini $\% 0,27 \pm \% 0,92(p=0,7585)$ oranında düşürerek ortak bir etki yarattı.

Sonuç: Epo uygulamasının MPV düzeyleri üzerinde kayda değer olmayan bir kısa vadeli azalma etkisi olduğu görüldü.

Anahtar Sözcükler: Hipoksi, eritropoietin, reoksijenasyon, ortalama trombosit hacmi
Address for Correspondence/Yazıșma Adresi: Constantinos Tsompos Mesologi County Hospital, Clinic of Obstetrics and Gynecology, Mesologi, Greece E-mail: tsomposconstantinos@gmail.com

Received/Geliş Tarihi: 14 August 2016 Accepted/Kabul Tarihi: 16 November 2016 ${ }^{\text {CCopyright }} 2016$ by The Medical Bulletin of
Haseki Training and Research Hospital The Medical Bulletin of Haseki published by Galenos Yayınevi. ๑Telif Hakkı 2016 Haseki Eğitim ve Araştırma Hastanesi Haseki Tıp Bülteni, Galenos Yayınevi tarafından basıımıştır. 


\section{Introduction}

Erythropoietin (Epo) is probably the most well-studied growth factor. Epo is included in over 29.025 known biomedical studies at present. At least $8.77 \%$ of these experiments concern tissue hypoxia-reoxygenation (HR) models. In addition, a noteworthy progress has been achieved regarding the Epo usage in transient or permanent HR injury repair including adjacent tissues, organs and certainly the patients' health. However, basic questions regarding dosage, administration timing and action velocity have not been answered yet. The knowledge must be promoted away from the original action of Epo in stem blood cells reproduction. However, specific HR matters have not been completely studied. A numeric evaluation of the Epo influence is provided by a meta-analysis of 32 published serum variables, based on the same experiment, for the same endpoints (Table 1). Mean platelet volume (MPV) is a variable produced by machine-calculated measurements. It reflects the average size of platelets found in blood and is typically included in complete blood count tests. When the body produces increased numbers of platelets, the average platelet size is larger. MPV test results can infers about platelet production in bone marrow or platelet destruction problems. The MPV variable is higher upon platelets destruction. This happens in Bernard-Soulier syndrome, myeloproliferative diseases, immune thrombocytopenic purpura and inflammatory bowel disease (1). It may also implicate the recovery from transient hypoplasia and preeclampsia (2). Impaired stem production as in aplastic anemia may correlate with abnormally low MPV values as in thrombocytopenia. Low MPV values can correlate with abnormally small platelet size, sometimes a symptom of a genetic spectrum referred to as Wiskott-Aldrich syndrome (3). The typical range of 9.7-12.8 femtolitre ( $\mathrm{fL}$ ) platelet volumes equals to spheres 2.65 to $2.9 \mu \mathrm{m}$ in diameter. The normal range is 7.5-11.5 fL (4). The aim of this experiment was to estimate the effect of Epo on a rat model, especially in a HR protocol. The effects of that factor were studied by measuring blood MPV values.

\section{Methods}

\section{Animal Preparation}

A Prefectural vet in East Attiki provided the experiment 3693/12-11-2010 and 14/10-1-2012 licenses. ELPEN Pharmaceuticals Co. Inc. S.A. in Pikermi, Attiki, granted all substances, equipment and required consumables. Appropriate humanistic animal care was adopted for female albino Wistar rats. One week pre-experimental normal housing in laboratory included ad libitum diet. Prenarcosis electrocardiogram, acidometry and oxygen supply preceded nonstop intra-experimental general anesthesia (5-12), post-experimental euthanasia did not permit preservation of the rodents. 40 rodents were randomly delivered to four equal experimental groups. All the 40 rats had the preceded hypoxia stage of 45 min induced by laparotomic forceps clamping the inferior aorta over the renal arteries. Afterwards, the clamp removal restored the inferior aorta patency and reoxygenation. Reoxygenation of 60 min was followed in group A. Reoxygenation of 120 min was followed in group B. Reoxygenation of $60 \mathrm{~min}$ and intravenous (iv) Epo administration was followed in group C. Reoxygenation of 120 min and iv Epo administration were followed in group D. The Epo dosage was $10 \mathrm{mg} / \mathrm{kg}$ body mass per animal. Epo was administered at the time of reoxygenation through catheterized inferior vena cava. MPV evaluations were performed at $60 \mathrm{~min}$ of reoxygenation for $A$ and $C$ groups and at 120 min of reoxygenation for $B$ and $D$ groups. The mean mass of the 40 female Wistar albino rats was $247.7 \mathrm{~g}$ [standard deviation (SD): $34.99172 \mathrm{~g}$; range: $165 \mathrm{~g}-320 \mathrm{~g}$ ]. Rats' mass could be probably a confusing factor, e.g. the more thin rats to have lower MPV levels. That assumption was also tested.

\section{Model of Hypoxia-reoxygenation Injury Control Groups}

Twenty control rats with a mean mass of $252.5 \mathrm{~g}$ [SD: $39.31988 \mathrm{~g}$ ] experienced $45 \mathrm{~min}$ hypoxia followed by reoxygenation.

Group A: Reoxygenation lasted 60 min with a mean mass of $243 \mathrm{~g}$ [SD: $45.77724 \mathrm{~g}$ ] and mean MPV level of $6.15 \mathrm{fL}$ [SD: $0.347211 \mathrm{fL}$ ] (control rats $\mathrm{n}=10$ ) (Table 2).

Group B: Reoxygenation lasted 120 min with a mean mass of $262 \mathrm{~g}$ [SD: $31.10913 \mathrm{~g}$ ] and mean MPV level of $6.51 \mathrm{fL}$ [SD: $0.4433459 \mathrm{fL}$ ] (control rats $\mathrm{n}=10$ ) (Table 2).

Erythropoietin group

Twenty Epo rats with a mean mass of $242.9 \mathrm{~g}$ [SD: $30.3105 \mathrm{~g}$ ] experienced $45 \mathrm{~min}$ hypoxia followed by reoxygenation along with $10 \mathrm{mg}$ iv Epo/kg body weight.

Group C: Reoxygenation lasted 60 min with a mean mass of $242.8 \mathrm{~g}$ [SD: $29.33636 \mathrm{~g}$ ] and mean MPV level of $6.39 \mathrm{fL}$ [SD: $0.6756889 \mathrm{fL}$ ] (Epo rats $\mathrm{n}=10$ ) (Table 2).

Group D: Reoxygenation lasted 120 min with a mean mass of $243 \mathrm{~g}$ [SD: $32.84644 \mathrm{~g}$ ] and mean MPV level of $6.25 \mathrm{fL}[\mathrm{SD}: 0.5502525 \mathrm{fL}$ ] (Epo rats n=10) (Table 2).

\section{Statistical Analysis}

Each group was compared with each one from three other groups for mass and MPV values applying successive statistical standard t-tests (Table 3). If any possible significant difference among MPV values was appeared, further investigation would be made for any respective possible significant difference in mass (Table 3). Then, the generalized linear models (GLM) were applied. They included MPV values as a dependant variable. The three independent variables were the Epo or no administration, 
the reoxygenation time and their interaction. Inserting the rats' mass as forth independent variable in GLM, a non significant correlation was turned on with MPV values $(p=0.3951)$, so as to further investigation was interrupted. The statistical analysis was made by Stata 6.0 statistical software [Stata 6.0, StataCorp LP, Texas, USA].

\section{Results}

Epo administration non-significantly reduced the MPV values by $0.01 \mathrm{fL}(-0.3454506 \mathrm{fL},-0.3254508 \mathrm{fL})$ $(p=0.9522)$. This finding was the same with the standard t-test $(p=0.9505)$. Reoxygenation time non-significantly augmented the MPV values by $0.11 \mathrm{fL},[-0.223516$

\begin{tabular}{|c|c|c|c|c|c|c|c|c|}
\hline Variable & 1h rep & p & $1.5 \mathrm{~h}$ rep & p & $2 \mathrm{~h}$ rep & $p$ & $\begin{array}{l}\text { Interaction of } \\
\text { Epo and rep }\end{array}$ & $p$ \\
\hline White BCC & $+24.01 \% \pm 13.38 \%$ & 0.1012 & $+22.09 \% \pm 9.11 \%$ & 0.0163 & $+20.17 \% \pm 12.94 \%$ & 0.0902 & $+14.63 \% \pm 5.40 \%$ & 0.0080 \\
\hline Red BCC & $+1.45 \% \pm 3.31 \%$ & 0.6589 & $+0.37 \% \pm 3.02 \%$ & 0.9048 & $-0.70 \% \pm 4.68 \%$ & 0.8844 & $+0.81 \% \pm 1.79 \%$ & 0.6446 \\
\hline Hematocrit & $+0.14 \% \pm 2.89 \%$ & 0.9626 & $-0.61 \% \pm 2.37 \%$ & 0.8072 & $-1.37 \% \pm 4.05 \%$ & 0.7485 & $+0.24 \% \pm 1.38 \%$ & 0.8586 \\
\hline $\begin{array}{l}\text { Hemoglobin } \\
\text { (10) }\end{array}$ & $+4.09 \% \pm 5.20 \%$ & 0.3350 & $+2.15 \% \pm 2.63$ & 0.4527 & $+0.20 \% \pm 5.08 \%$ & 0.9584 & $+1.31 \% \pm 1.59 \%$ & 0.3984 \\
\hline $\mathrm{MCH}$ & $+0.01 \% \pm 1.29 \%$ & 0.9904 & $+0.67 \% \pm 0.80 \%$ & 0.3549 & $+1.34 \% \pm 1.08 \%$ & 0.1509 & $-0.36 \% \pm 0.47 \%$ & 0.4430 \\
\hline MCV (9) & $+0.01 \% \pm 1.08 \%$ & 0.9904 & $+0.56 \% \pm 0.66 \%$ & 0.3549 & $+1.12 \% \pm 0.91 \%$ & 0.1509 & $+0.30 \% \pm 0.39 \%$ & 0.4430 \\
\hline $\mathrm{MCHC}(7)$ & $+1.82 \% \pm 0.56 \%$ & 0.0076 & $+1.73 \% \pm 0.50 \%$ & 0.0016 & $+1.65 \% \pm 0.92 \%$ & 0.0721 & $+0.89 \% \pm 0.31 \%$ & 0.0061 \\
\hline RBC DW & $-1.85 \% \pm 4.24 \%$ & 0.6703 & $-1.64 \% \pm 2.53 \%$ & 0.5159 & $-1.43 \% \pm 3.34 \%$ & 0.6078 & $-1.06 \% \pm 1.43 \%$ & 0.4733 \\
\hline Platelet crit (6) & $-7.32 \% \pm 13.11 \%$ & 0.5219 & $-2.14 \% \pm 8.04 \%$ & 0.7581 & $+3.04 \% \pm 10.78 \%$ & 0.7204 & $-0.16 \% \pm 4.76 \%$ & 0.9725 \\
\hline Platelet DW & $\pm 1.60 \% \pm 0.80 \%$ & 0.0765 & $+1.36 \% \pm 0.58 \%$ & 0.0205 & $\pm 1.13 \% \pm 0.74 \%$ & 0.1152 & $\pm 0.37 \% \pm 0.37 \%$ & 0.0615 \\
\hline Platelet crit & $-16.47 \% \pm 10.40 \%$ & 0.0921 & $-13.74 \% \pm 7.01 \%$ & 0.0158 & $-11.01 \% \pm 7.34 \%$ & 0.0882 & $-6.88 \% \pm 3.69 \%$ & 0.0615 \\
\hline Glucose (11) & $+0.75 \% \pm 8.11 \%$ & 0.9307 & $+5.59 \% \pm 6.46 \%$ & 0.3208 & $+10.44 \% \pm 10.99 \%$ & 0.3491 & $+4.94 \% \pm 3.81 \%$ & 0.1892 \\
\hline Urea & $+21.42 \% \pm 7.84 \%$ & 0.0115 & $+20.11 \% \pm 7.25 \%$ & 0.0059 & $+18.80 \% \pm 9.44 \%$ & 0.0709 & $+15.64 \% \pm 4.04 \%$ & 0.0003 \\
\hline Creatinine & $-0.10 \% \pm 9.78 \%$ & 0.9904 & $-4.84 \% \pm 5.78 \%$ & 0.3721 & $-9.59 \% \pm 7.74 \%$ & 0.1509 & $-2.62 \% \pm 3.49 \%$ & 0.4430 \\
\hline Uric acid & $+10.13 \% \pm 15.10 \%$ & 0.4917 & $+15.86 \% \pm 10.21 \%$ & 0.1408 & $+21.59 \% \pm 15.45 \%$ & 0.1940 & $+9.33 \% \pm 6.16 \%$ & 0.1264 \\
\hline Total Protein & $-0.02 \% \pm 2.47 \%$ & 0.9904 & $-1.27 \% \pm 1.51 \%$ & 0.3721 & $-2.52 \% \pm 2.03 \%$ & 0.1509 & $-0.68 \% \pm 2.48 \%$ & 0.4430 \\
\hline Albumin & $-4.61 \% \pm 4.21 \%$ & 0.2530 & $-9.28 \% \pm 3.20 \%$ & 0.0054 & $-13.96 \% \pm 5.03 \%$ & 0.0095 & $-5.37 \% \pm 2.73 \%$ & 0.0072 \\
\hline ALT & $+18.89 \%+12.42 \%$ & 0.1372 & $+7.63 \%+18.94 \%$ & 0.6396 & $-3.63 \%+25.19 \%$ & 0.8617 & $+8.03 \% \pm 11.36 \%$ & 0.4698 \\
\hline AST & $+29.53 \% \pm 9.72 \%$ & 0.0096 & $+26.71 \% \pm 13.17 \%$ & 0.0235 & $+23.89 \% \pm 21.59 \%$ & 0.1709 & $+19.73 \% \pm 7.70 \%$ & 0.0119 \\
\hline GT & $-19.35 \% \pm 18.58 \%$ & 0.2362 & $-12.70 \% \pm 13.11 \%$ & 0.3541 & $-6.06 \% \pm 19.96 \%$ & 0.7800 & $-4.62 \% \pm 7.97 \%$ & 0.5534 \\
\hline ALP & $+0.20 \% \pm 18.57 \%$ & 0.9904 & $+10.70 \% \pm 12.78 \%$ & 0.3549 & $+21.20 \% \pm 17.11 \%$ & 0.1509 & $+5.79 \% \pm 7.72 \%$ & 0.4430 \\
\hline $\mathrm{ACP}$ & $+0.06 \% \pm 5.79 \%$ & 0.9904 & $+3.11 \% \pm 3.71 \%$ & 0.3172 & $+6.16 \% \pm 4.97 \%$ & 0.1509 & $+1.68 \% \pm 2.23 \%$ & 0.4430 \\
\hline CPK & $+0.15 \% \pm 14.09 \%$ & 0.9904 & $+7.91 \% \pm 9.44 \%$ & 0.3549 & $+15.67 \% \pm 12.65 \%$ & 0.1509 & $+4.28 \% \pm 5.70 \%$ & 0.4430 \\
\hline CK-MB (8) & $+0.08 \% \pm 7.90 \%$ & 0.9904 & $+4.28 \% \pm 5.11 \%$ & 0.3721 & $+8.49 \% \pm 6.85 \%$ & 0.1509 & $+2.32 \% \pm 3.09 \%$ & 0.4430 \\
\hline LDH & $+0.08 \% \pm 7.92 \%$ & 0.9904 & $+4.48 \% \pm 5.35 \%$ & 0.3549 & $+8.89 \% \pm 7.17 \%$ & 0.1509 & $+2.42 \% \pm 3.22 \%$ & 0.4430 \\
\hline Sodium & $+0.72 \% \pm 0.74 \%$ & 0.3054 & $+0.21 \% \pm 0.63 \%$ & 0.7136 & $-0.29 \% \pm 1.09 \%$ & 0.7670 & $-0.11 \% \pm 0.38 \%$ & 0.7531 \\
\hline Potassium & $-6.17 \% \pm 4.94 \%$ & 0.1540 & $-2.21 \% \pm 3.66 \%$ & 0.5134 & $+1.74 \% \pm 5.43 \%$ & 0.7299 & $+0.18 \% \pm 2.22 \%$ & 0.9338 \\
\hline Calcium & $0.28 \% \pm 1.19 \%$ & 0.8065 & $-0.56 \% \pm 1.13 \%$ & 0.5761 & $-1.41 \% \pm 2.08 \%$ & 0.4100 & $-0.34 \% \pm 0.68 \%$ & 0.6095 \\
\hline Phosphorus & $+1.92 \% \pm 5.25 \%$ & 0.6982 & $+3.95 \% \pm 3.35 \%$ & 0.2100 & $+5.98 \% \pm 4.81 \%$ & 0.2930 & $\pm 2.45 \% \pm 2.01 \%$ & 0.2168 \\
\hline Magnesium & $\pm 1 \% \pm 6.20 \%$ & 0.8596 & $-1.09 \% \pm 3.34 \%$ & 0.7248 & $-3.19 \% \pm 3.90 \%$ & 0.3729 & $-0.19 \% \pm 1.93 \%$ & 0.9197 \\
\hline Amylase & $\pm 6.50 \% \pm 9.15 \%$ & 0.4161 & $\pm 5.04 \% \pm 6.12 \%$ & 0.3831 & $\pm 3.59 \% \pm 8.42 \%$ & 0.6649 & $\pm 4.36 \% \pm 3.65 \%$ & 0.2258 \\
\hline Progesteron & $-0.20 \% \pm 18.65 \%$ & 0.9904 & $-8.86 \% \pm 10.58 \%$ & 0.3549 & $-17.53 \% \pm 14.15 \%$ & 0.1509 & $-4.79 \% \pm 6.39 \%$ & 0.4430 \\
\hline Mean & $\pm 2.15 \% \pm 9.92 \%$ & 0.5824 & $\pm 2.67 \% \pm 9.06 \%$ & 0.3645 & $\pm 3.2 \% \pm 10.34 \%$ & 0.3583 & $\pm 2.26 \% \pm 5.91 \%$ & 0.4041 \\
\hline
\end{tabular}

Rep: Reperfusion, Epo: Erythropoietin, LDH: Lactate dehydrogenase, CK-MB: Creatine kinase, CPK: Creatine phosphokinase with isoenzymes, ACP: Acid phosphatase, AST: Aspartate aminotransferase, ALP: Alkaline phosphatase, ALT: Alanine aminotransferase 
$f L,-0.4435162 \mathrm{fL}](p=0.5084)$ also the same with the standard t-test $(p=0.4663)$. However, epo administration and reoxygenation time together nonsignificantly reduced the MPV values by $0.03 \mathrm{fL}[-0.2329483 \mathrm{fL},-0.1711302$ $f L](p=0.7585)$. The Tables 4 and 5 depict the alteration influence of Epo versus reoxygenation time, after process of the above results with the data of Table 3 .

\section{Discussion}

Hypoxia may influence MPV levels. Tsompos et al. (9) concluded that MPV was associated with acute ischemic stroke severity and it was of high value for discriminating severe from mild ischemic stroke $(p=0.012)$. Tsompos et al. (10) identified MPV levels [6.5 fL to $11.7 \mathrm{fL}$ ] as an independent predictor of the presence of slow coronary flow ( $p=0.03$ ). Tsompos et al. (11) measured significantly higher MPV values 24 hours after stroke $(p=0.001)$ in patients than in controls on admission. Increased platelet size contributes to the progression of ischemic stroke.

\begin{tabular}{|c|c|c|c|}
\hline Groups & Variable & Mean & Standard deviation \\
\hline \multirow[t]{2}{*}{ A } & Weight & $243 \mathrm{~g}$ & $45.77724 \mathrm{~g}$ \\
\hline & MPV & $6.15 \mathrm{fL}$ & $0.347211 \mathrm{fL}$ \\
\hline \multirow[t]{2}{*}{ B } & Weight & $262 \mathrm{~g}$ & $31.10913 \mathrm{~g}$ \\
\hline & MPV & $6.51 \mathrm{fL}$ & $0.4433459 \mathrm{fL}$ \\
\hline \multirow[t]{2}{*}{ C } & Weight & $242.8 \mathrm{~g}$ & $29.33636 \mathrm{~g}$ \\
\hline & MPV & $6.39 \mathrm{fL}$ & $0.6756889 \mathrm{fL}$ \\
\hline \multirow[t]{2}{*}{ D } & Weight & $243 \mathrm{~g}$ & $32.84644 \mathrm{~g}$ \\
\hline & MPV & $6.25 \mathrm{fL}$ & $0.5502525 \mathrm{fL}$ \\
\hline \multicolumn{3}{|c|}{ MPV: Mean platelet volume } & \\
\hline
\end{tabular}

Table 3. Statistical significance of mean values difference for groups after statistical standard $\mathbf{t}$ test application

\begin{tabular}{|c|c|c|c|}
\hline DG & Variable & Difference & $p$ \\
\hline \multirow[t]{2}{*}{$A-B$} & Weight & $-19 g$ & 0.2423 \\
\hline & MPV & $-0.36 \mathrm{fL}$ & 0.0820 \\
\hline \multirow[t]{2}{*}{$A-C$} & Weight & $0.2 \mathrm{~g}$ & 0.9900 \\
\hline & MPV & $0.24 \mathrm{fL}$ & 0.2901 \\
\hline \multirow[t]{2}{*}{$A-D$} & Weight & $0 \mathrm{~g}$ & 10000 \\
\hline & MPV & -0.10 & 0.3676 \\
\hline \multirow[t]{2}{*}{$B-C$} & Weight & $19.2 \mathrm{~g}$ & 0.2598 \\
\hline & MPV & $0.12 \mathrm{fL}$ & 0.6633 \\
\hline \multirow[t]{2}{*}{ B-D } & Weight & $19 \mathrm{~g}$ & 0.1011 \\
\hline & MPV & $0.26 \mathrm{fL}$ & 0.2618 \\
\hline \multirow[t]{2}{*}{ C-D } & Weight & $-0.2 \mathrm{~g}$ & 0.9883 \\
\hline & MPV & $0.14 \mathrm{fL}$ & 0.5245 \\
\hline
\end{tabular}

Damaske et al. (12) found increased MPV values in patients with slow coronary flow than in controls. Ertas et al. (13) stated that increased MPV was an independent predictor of mortality in patients with chronic heart failure $(p=0.004)$. Açikgöz et al. (14) noted significantly higher MPV values in patients with ischemic cardiomyopathy regardless of the etiology compared to those in controls $(p<0.001)$. Ntaios et al. (15) showed that MPV was significantly increased in acute ischemic non-lacunar strokes 24 hours after stroke onset and related them with poor functional outcome. Slavka et al. (16) concluded that patients with increased MPV values $(\geq 11.01 \mathrm{fL}$ ) were at a higher risk of ischemic heart disease. Ilhan et al. (17) found a significant difference in MPV levels between patients with symptomatic lacunar stroke infarcts and controls $(p<0.01)$. Mayda-Domac et al. (18) observed that MPV was an independent risk factor for ischemic stroke $(p=0.007)$ and hemorrhagic stroke $(p=0.001)$. In their study evaluating MPV within 30 hours since stroke onset, Pikija et al. (19) reported that higher MPV values were associated with larger infarct volume $(p=0.046)$, greater risk of short-term and greater risk of death/dependence 7 days post-stroke ( $p=0.036$ and 0.048 , respectively), and MPV was a determinant of severity and outcome

\begin{tabular}{|c|c|c|c|c|}
\hline \multirow[t]{2}{*}{ Change } & $95 \%$ c. in. & $\begin{array}{l}\text { Reoxygenation } \\
\text { time }\end{array}$ & $\mathrm{p}$ & \\
\hline & & & t-test & GLM \\
\hline$+0.24 \mathrm{fL}$ & $\begin{array}{l}-0.2647072 \mathrm{fL}- \\
0.7447075 \mathrm{fL}\end{array}$ & $1 \mathrm{~h}$ & 0.2901 & 0.3310 \\
\hline$-0.01 \mathrm{fL}$ & $\begin{array}{l}-0.3454506 \mathrm{fL}- \\
0.3265508 \mathrm{fL}\end{array}$ & $1.5 \mathrm{~h}$ & 0.9505 & 0.9522 \\
\hline$-0.26 \mathrm{fL}$ & $\begin{array}{l}-0.7294672 \mathrm{fL}- \\
0.2094671\end{array}$ & $2 \mathrm{~h}$ & 0.2618 & 0.2598 \\
\hline$+0.11 \mathrm{fL}$ & $\begin{array}{l}-0.223516 \mathrm{fL}- \\
0.4435162 \mathrm{fL}\end{array}$ & - & 0.4663 & 0.5084 \\
\hline$-0.03 f L$ & $\begin{array}{l}-0.2329483 \mathrm{fL}- \\
0.1711302 \mathrm{fL}\end{array}$ & - & 0.7585 & - \\
\hline \multicolumn{2}{|c|}{ GLM: Generalized linear models } & & & \\
\hline
\end{tabular}

Table 5. The (\%) alteration influence of erythropoietin in connection with reperfusion time

\begin{tabular}{|l|l|l|l|}
\hline Change & \pm Standard deviation & Reperfusion time & $\mathbf{p}$ \\
\hline$+3.82 \%$ & $\pm 4.10 \%$ & $1 \mathrm{~h}$ & 0.3105 \\
\hline$-0.12 \%$ & $\pm 2.13 \%$ & $1.5 \mathrm{~h}$ & 0.9513 \\
\hline$-4.07 \%$ & $\pm 3.75 \%$ & $2 \mathrm{~h}$ & 0.2608 \\
\hline$+1.37 \%$ & $\pm 2.11 \%$ & - & 0.4873 \\
\hline$-0.27 \%$ & $\pm 0.92 \%$ & Interaction & 0.7585 \\
\hline
\end{tabular}


of the acute ischemic stroke. Durmaz et al. (20) found higher MPV in aspirin nonresponder stable coronary artery disease patients than in responders. Yetkin (21) stated that MPV was independently associated with ischemic electrocardiographic changes in elderly population. Muscari et al. (22) found an association between MPV values and the prevalence of ischemic ECG alterations $(p=0.004)$ in elderly population. In their study, Bitigen et al. (23) found that MPV values in patients with isolated coronary artery ectasia were significantly higher than in controls, and they suggested that increased MPV might be associated with ischemic events $(p<0.0001)$. Ihara et al. (24) demonstrated a significant relationship between MPV and ischemic heart disease. In their another study, Ihara et al. (25) found significantly higher MPV levels in patients with negative angiograms than in those with positive ones. Nadar et al. (26) found lower MPV values in patients with acute stroke compared to uncomplicated hypertensive patients who had significantly higher MPV values than normal controls. McCabe et al. (27) supported the hypothesis that reticulated platelets are larger than more mature 'non-reticulated' platelets in ischemic cerebrovascular disease $(p<0.01)$. Greisenegger et al. (28) demonstrated that patients within the highest quintile of MPV had a significantly higher risk of severe stroke and worse outcome, compared with those within the lowest quintile $(p=0.013)$. O'Malley et al. (29) found higher MPV levels measured within 48 hours after acute stroke $(p<0.001)$ and in available survivors. They stated that an increase in MPV and a reduction in platelet count were features of both acute and nonacute phases of cerebral ischemia. Kristensen et al. (30) defined high MPV as a risk factor for myocardial infarction (MI) patients and death in patients with a recent MI. Legrand et al. (31) described the occurrence of platelet fragmentation in the circulation in patients with ischemic cerebrovascular disease. Dudley et al. (32) set 5 criteria but MPV levels failed such as to distinguish primary thrombocythemia from reactive thrombocytosis.

Epo may also influence MPV levels. Asanuma et al. (33) noted that MPV levels were slightly higher in hemodialysis $(\mathrm{HD})$ patients receiving recombinant human $(\mathrm{rHu})$ Epo at $9000 \mathrm{IU} /$ week than in healthy controls. Kirkeby et al. (34) reported that treatment with Epo $(50 \mu \mathrm{g} / \mathrm{kg})$ increased MPV levels by $37 \%$ in rats. Kapsoritakis et al. (35) found significantly decreased MPV values in patients with active inflammatory bowel diseases such as ulcerative colitis and Crohn's disease compared to those with inactive disease and healthy controls. Weisbach et al. (36) suggested a pronounced rise in Epo after platelet collection apheresis procedure as a stimulus for a subsequent thrombopoiesis that expands to initiate early megakaryocytopoiesis.
Sowade et al. (37) observed that preoperative hematocrit increase in rHu-Epo-treated patients was accompanied with an MPV drop in patients undergoing cardiac surgery. Bath et al. (38) found that MPV was increased by $0.4 \mathrm{fL}$ in patients with autosomal dominant polycystic kidney disease (ADPKD). They suggested that increased MPV in ADPKD may be a marker and may contribute to the development of premature vascular disease and sudden cardiac death. Krzeslowska et al. (39) demonstrated significant rises in MPV by 4 month treatment of HD patients with rHu-Epo. In their study investigating the toxicity profile of recombinant human interleukin-6 (rhIL-6) and its effect on hematopoiesis, biochemical parameters and other cytokines, van Gameren et al. (40) found that MPV was decreased in 20 patients with breast carcinoma or nonsmall cell lung cancer receiving rhIL-6 kg/d. Sharpe et al. (41) got on increased MPV levels, megakaryocyte development and thrombosis risk $(p<0.001)$ after six months rHu-Epo administration in chronic renal failure patients than in controls. Fabris et al. (42) reported that MPV levels were decreased in anemic children with end-stage renal disease after 6 and 12 weeks of rHu-Epo treatment. In a study by Akizawa et al. (43) MPV was significantly increased in HD patients with renal anemia 12 weeks after $\mathrm{rHu}$-Epo therapy (stage II) compared with pretreatment (stage I). Kinugasa et al. (44) reported a significant increase in MPV in patients with renal anemia receiving HD 12 weeks after iv administration of 3000 IU rHu-Epo at the end of every HD session and 6 weeks after rHuEpo discontinuation compared with pretreatment state. MPV values cannot be dissociated from platelet count, coagulation physiology and blood clotting. Furthermore, in their study investigating the effects of Gynura segetum in rats with hepatic veno-occlusive disease, Fang et al. (45) found an association of increase in MPV values with increased platelet distribution, prothrombin time (PT), thrombin time, activated partial thromboplastin time (APTT), prothrombin ratio and international normalized ratio (INR), but with decreased PT\%, fibrinogen level and platelet aggregation $(p<0.05)$, platelet count and plateletcrit, as well as blood clotting time and platelet aggregation. Qureshi and Kanwal (46) investigated dosedependent anticoagulation effect of kisspeptin via in vivo administration of kisspeptin to laboratory rats. They have found that following in vivo kisspeptin administration, coagulation time, bleeding time, PT, and APTT were significantly prolonged; INR was increased, while serum calcium concentration and mean platelet count were significantly declined. MPV was increased only at the highest tested dose. Yuce et al. (47) considered MPV as a marker of platelet size and platelet function determinant 
since larger platelets are hemostatically more reactive than normal size platelets, increasing the propensity to thrombosis. In a study evaluating the efficiency and effectiveness of batch preparing cryopreserved fresh platelet-rich plasma, Ouyang et al. (48) showed that plasma clotting time induced by cryopreserved fresh platelet-rich plasma was significantly shorter than that induced by fresh platelet-rich plasma. Teitel (49) JM52 claimed that coagulation defects lead to impaired fibrin clot formation and delayed bleeding after primary hemostasis is characteristic of hyperfibrinolysis. Van der Planken et al. (50) who have studied platelet prothrombinase activity and investigated its correlation with microvascular disease and MPV, found no difference either in MPV or in platelet mass between diabetic and control plateletrich plasma. The outer layer of platelet phospholipid membrane is more pro-coagulant than in quiescent state, stimulating the thrombin formation in plasma. This platelet phenomenon is called platelet pro-coagulant activity. Gunsilius et al. (51) calculated the vascular endothelial growth factor content per 109 platelets at $2.51+2.39$ pg as dependent on MPV levels. Van der Planken et al. (52) evaluated the evolution of platelet procoagulant activity and the MPV of stored platelets prepared using the platelet-rich method (PRM) and the buffy coat method (BCM). They found that the MPV of BCM concentrates was significantly higher $(p<0.0005)$ than the MPV of PRM concentrates at any storage day. Higher platelet procoagulant activity expression in BCM concentrates may be explained by an intrinsic platelet property, such as their difference in MPV values. Nelson et al. (55) measured significantly increased MPV values $(p<0.01)$; shortened PT by $1 \mathrm{sec}(p<0.01)$ during the consumption period of dietary n-3 fatty acids with salmon diet. van Wersch et al. (54) found a significant decline in platelet counts, MPV and total thrombocytic clotting capacity with training for a $42-\mathrm{km}$ run. Mammen et al. (55) found a marked increase in all clotting factors and measured near normal levels 48 hours post-operatively in patients undergoing cardiopulmonary bypass operation. Platelet counts remained low, however, the decrease in factors rarely dropped below the compromised hemostasis level $(<30 \%)$. Although antithrombin levels decreased below $60 \%$, the heparinization was not compromised. A significant drop in MPV was recorded upon protamin administration. Twenty-four hours post-operatively, the MPV were normal again. MPV is considered a rather insignificant variable when evaluating the clotting situations. However, the above literature confirms the hypothesis of competition between precursor stem cells of the erythrocytic and megakaryocytic cell lines (stem-cell competition) as the cause of thrombocytopenia in Epo-treated individuals until
5 days from Epo administration. After the $5^{\text {th }}$ day, the impact on platelet count, MPV and coagulation increases, nevertheless, in either endpoint, the role of MPV is not subordinate to other platelet characteristics and should be taken into consideration when assessing the clotting profiles. In particular, MPV alterations have immediate clinical significance accordant with the majority of the literature: MPV augmentations increase the coagulation as well. The acute or short-term ( $<5$ days) effect of Epo on MPV levels is confusing and not significant by the present experiment. However, if the competitive hypothesis and the parallel action of Epo on platelet count and MPV is accepted, thus, the non-significant acute reducing effect of Epo on MPV (by $0.27 \%+0.92 \% p=0.7585$ ) from the present experiment must also be accepted. Given the short-term anti-coagulation tendency of Epo through MPV decline, the resultant short-term effect of Epo on the clotting tendency of blood can be determined only by the most appropriate assays evaluating the extrinsic pathway of coagulation. These assays which unpleasantly were not included in the present experiment are the PT, the prothrombin ratio (PR) and the INR that must be evaluated in a future experiment.

\section{Conclusion}

Epo administration had non-significant short-term MPV lowering effects along with resultant clot attenuating one. Longer study periods, exactly longer than 5 days, reverse these effects. Nevertheless, the total coagulation tendency of Epo can be revealed only after PT, PR and INR evaluation inclusion in a future experiment.

Acknowledgment: This study was funded by Scholarship by the Experimental Research Center ELPEN Pharmaceuticals (E.R.C.E), Athens, Greece. The research facilities for this project were provided by the aforementioned institution. This study was funded by Scholarship by the Experimental.

\section{Ethics}

Ethics Committee Approval: It was taken. Informed Consent: Consent form was filled out by all participants.

Peer-review: Externally and Internally peer-reviewed.

\section{Authorship Contributions}

Surgical and Medical Practices: George Zografos. Concept: Apostolos Papalois. Design: Constantinos Panoulis. Data Collection or Processing: Constantinos Tsompos. Analysis or Interpretation: Konstantinos Toutouzas. Literature Search: Aggeliki Triantafyllou. Writing: Constantinos Tsompos.

Conflict of Interest: No conflict of interest was declared by the authors. 
Financial Disclosure: The authors declared that this study received no financial support.

\section{References}

1. Liu S, Ren J, Han G, et al. Mean platelet volume: a controversial marker of disease activity in Crohn's disease. Eur J Med Res 2012;17:27.

2. Lippi G, Filippozzi L, Salvagno GL, et al. Increased mean platelet volume in patients with acute coronary syndromes. Arch Pathol Lab Med 2009;133:1441-3.

3. http://primaryimmune.org/about-primaryimmunodeficiencies/ specificdisease- types/wiskott-aldrich-syndrome.

4. http://www.diabetesexplained.com/mean-platelet-volume. html.

5. Tsompos C, Panoulis C, Toutouzas K, et al. The Effect of Erythropoietin on Aspartate Aminotransferase Levels during Ischemia Reperfusion Injury in Rats. Electronic Journal of Biology 2016;12:161-7.

6. Tsompos C, Panoulis C, Toutouzas K, et al. The acute trend of erythropoietin on platelet count during hypoxia reoxygenation injury in rats. Medical Channel Karachi 2016;22:7-13.

7. Tsompos C, Panoulis C, Toutouzas K, et al. The acute effect of erythropoietin on mean corpuscular hemoglobin concentration levels during hypoxia - reoxygenation injury in rats. J Med Soc 2016;30:79-83.

8. Tsompos C, Panoulis C, Toutouzas K, et al. The effect of erythropoietin on creatine kinase MB levels during hypoxia reoxygenation injury in rats. J Pharmacol Toxicol 2015;1:51-3.

9. Tsompos C, Panoulis C, utouzas K, Triantafyllou A, ografos $G$, Papalois A. The acute effect of erythropoietin on mean corpuscular volume levels during hypoxia-reoxygenation injury in rats. Journal of Cellular Biotechnology 2 (2016) 77-83.

10. Tsompos C, Panoulis C, utouzas K, Triantafyllou A, ografos G, Papalois A. The Short-Term Effect Of Erythropoietın On Hemoglobın Durıng Ischemia Reperfusıon Injury In Rats. Fiziologia 2013.23.3:26-32.

11. Tsompos C, Panoulis C, utouzas K, Triantafyllou A, ografos $G$, Papalois A. The Acute Effect of Erythropoietin on Glucose Levels during Ischemia Reperfusion Injury. FMI 2016;52:14-8.

12. Damaske A, Muxel S, Fasola F, et al. Peripheral hemorheological and vascular correlates of coronary blood flow. Clin Hemorheol Microcirc 2011;49:261-9.

13. Ertas G, Kozdag G, Emre E, et al. Effect of enhanced external counterpulsation treatment on mean platelet volume in patients affected by ischemic chronic heart failure. Blood Coagul Fibrinolysis 2012;23:127-31.

14. Açikgöz N, Ermiş N, Yağmur J. The evaluation of mean platelet volume levels in patients with idiopathic and ischemic cardiomyopathy: an observational study. Anatol J Cardiol 2011;11:595-9.

15. Ntaios G, Gurer O, Faouzi M, et al. Hypertension is an independent predictor of mean platelet volume in patients with acute ischaemic stroke. Intern Med J 2011;41:691-5.

16. Slavka G, Perkmann $T$, Haslacher $H$, et al. Mean platelet volume may represent a predictive parameter for overall vascular mortality and ischemic heart disease. Arterioscler Thromb Vasc Biol 2011;31:1215-8.
17. Ilhan D, Ozbabalik D, Gulcan E, et al. Evaluation of platelet activation, coagulation, and fibrinolytic activation in patients with symptomatic lacunar stroke. Neurologist 2010;16:188-91.

18. Mayda-Domac F, Misirli H, Yilmaz M. Prognostic role of mean platelet volume and platelet count in ischemic and hemorrhagic stroke. J Stroke Cerebrovasc Dis 2010;19:66-72.

19. Pikija S, Cvetko D, Hajduk $M$, et al. Higher mean platelet volume determined shortly after the symptom onset in acute ischemic stroke patients is associated with a larger infarct volume on CT brain scans and with worse clinical outcome. Clin Neurol Neurosurg 2009;111:568-73.

20. Durmaz T, Keles T, Ozdemir O, et al. Heart rate variability in patients with stable coronary artery disease and aspirin resistance. Int Heart J 2008;49:413-22.

21. Yetkin E. Mean platelet volume not so far from being a routine diagnostic and prognostic measurement. Thromb Haemost 2008;100:3-4.

22. Muscari A, De Pascalis S, Cenni A, et al. Determinants of mean platelet volume (MPV) in an elderly population: relevance of body fat, blood glucose and ischaemic electrocardiographic changes. Thromb Haemost 2008;99:1079-84.

23. Bitigen A, Tanalp AC, Elonu OH, et al. Mean platelet volume in patients with isolated coronary artery ectasia. J Thromb Thrombolysis 2007;24:99-103.

24. Ihara A, Kawamoto T, Matsumoto $K$, et al. Relationship between hemostatic factors and the platelet index in patients with ischemic heart disease. Pathophysiol Haemost Thromb 2006;35:388-91.

25. Ihara A, Kawamoto T, Matsumoto K, et al. Relationship between platelet indexes and coronary angiographic findings in patients with ischemic heart disease. Pathophysiol Haemost Thromb 2006;35:376-9.

26. Nadar SK, Lip GY, Blann AD. Platelet morphology, soluble $P$ selectin and platelet P-selectin in acute ischaemic stroke. The West Birmingham Stroke Project. Thromb Haemost 2004;92:1342-8.

27. McCabe DJ, Harrison P, Sidhu PS, et al. Circulating reticulated platelets in the early and late phases after ischaemic stroke and transient ischaemic attack. Br J Haematol 2004;126:861-9.

28. Greisenegger S, Endler G, Hsieh K, et al. Is elevated mean platelet volume associated with a worse outcome in patients with acute ischemic cerebrovascular events? Stroke 2004;35:1688-91.

29. O'Malley T, Langhorne P, Elton RA, et al. Platelet size in stroke patients. Stroke 1995;26:995-9.

30. Kristensen SD, Husted SE, Nielsen HK, et al. [Interaction between thrombocytes and blood vessel wall-significance for acute ischemic coronary syndromes]. Ugeskr Laeger 1995; 157:2295-8

31. Legrand C, Woimant F, Haguenau M, et al. Platelet surface glycoprotein changes in patients with cerebral ischemia. Nouv Rev Fr Hematol 1991;33:497-9.

32. Dudley JM, Messinezy M, Eridani S, et al. Primary thrombocythaemia: diagnostic criteria and a simple scoring system for positive diagnosis. Br J Haematol 1989;71:331-5. 
33. Asanuma M, Seino K, Mizuno T, et al. Plasma thrombopoietin level and platelet indices in hemodialysis patients receiving recombinant human erythropoietin. Int J Lab Hematol 2010;32:312-9.

34. Kirkeby A, Torup L, Bochsen L, et al. High-dose erythropoietin alters platelet reactivity and bleeding time in rodents in contrast to the neuroprotective variant carbamylerythropoietin (CEPO). Thromb Haemost 2008;99:720-8.

35. Kapsoritakis AN, Koukourakis MI, Sfiridaki A, et al. Mean platelet volume: a useful marker of inflammatory bowel disease activity. Am J Gastroenterol 2001;96:776-81.

36. Weisbach $V$, Friedlein $H$, Glaser $A$, et al. The influence of automated plateletpheresis on systemic levels of hematopoietic growth factors. Transfusion 1999;39:889-94.

37. Sowade O, Ziemer S, Sowade B, et al. The effect of preoperative recombinant human erythropoietin therapy on platelets and hemostasis in patients undergoing cardiac surgery. J Lab Clin Med 1997;129:376-83.

38. Bath PM, Saggar-Malik AK, Macdougall IC, et al. Original articles: increased platelet volume in patients with adult polycystic kidney disease. Platelets 1995;6:336-9.

39. Krzeslowska J, Rysz J, Cierniewski CS, et al. Expression of fibrinogen receptors and GPIlb molecules on uraemic platelets: effect of recombinant human erythropoietin therapy. Nephrol Dial Transplant 1995;10:653-6.

40. van Gameren MM, Willemse PH, Mulder NH, et al. Effects of recombinant human interleukin- 6 in cancer patients: a phase I-Il study. Blood 1994;84:1434-41.

41. Sharpe PC, Desai ZR, Morris TC. Increase in mean platelet volume in patients with chronic renal failure treated with erythropoietin. J Clin Pathol 1994;47:159-61.

42. Fabris F, Cordiano I, Randi ML, et al. Effect of human recombinant erythropoietin on bleeding time, platelet number and function in children with end-stage renal disease maintained by haemodialysis. Pediatr Nephrol 1991;5:225-8.

43. Akizawa T, Kinugasa E, Kitaoka T, et al. Effects of recombinant human erythropoietin and correction of anemia on platelet function in hemodialysis patients. Nephron 1991;58:400-6.

44. Kinugasa E, Nabeshima K, Niikura K, et al. [The effects of r-HuEPO on platelet function and coagulation factors in hemodialysis patients]. Nihon Jinzo Gakkai Shi 1990;32:1109-16.
45. Fang J, Zhang G, Teng X, et al. [Hematologic toxicity of Gynura segetum and effects on vascular endothelium in a rat model of hepatic veno-occlusive disease]. Zhonghua Gan Zang Bing Za Zhi 2015;23:59-63.

46. Qureshi IZ, Kanwal S. Novel role of puberty onset protein kisspeptin as an anticoagulation peptide. Blood Coagul Fibrinolysis 2011;22:40-9.

47. Yuce M, Cakici M, Davutoglu $V$, et al. Relationship between mean platelet volume and atrial thrombus in patients with atrial fibrillation. Blood Coagul Fibrinolysis 2010;21:722-5.

48. Ouyang $X L$, Liu JH, Pan JC, et al. [Qualitative analysis of batch preparing cryopreserved fresh platelet rich plasma]. Zhongguo Shi Yan Xue Ye Xue Za Zhi 2004;12:841-4.

49. Teitel JM. Clinical approach to the patient with unexpected bleeding. Clin Lab Haematol 2000;22(Suppl 1):9-11.

50. van der Planken MG, Vertessen FJ, Vertommen J, et al. Platelet prothrombinase activity, a final pathway platelet procoagulant activity, is overexpressed in type 1 diabetes: no relationship with mean platelet volume or background retinopathy. Clin Appl Thromb Hemost 2000;6:65-8.

51. Gunsilius E, Petzer A, Stockhammer G, et al. Thrombocytes are the major source for soluble vascular endothelial growth factor in peripheral blood. Oncology 2000;58:169-74.

52. van der Planken MG, Vertessen F, Mortelmans E, et al. The evolution of platelet procoagulant activity of remnant platelets in stored platelet concentrates prepared by the platelet-rich plasma method and the buffy coat method. Ann Hematol 1999;78:1-7.

53. Nelson GJ, Schmidt PC, Corash L. The effect of a salmon diet on blood clotting, platelet aggregation and fatty acids in normal adult men. Lipids 1991;26:87-96.

54. van Wersch JW, Kaiser V, Janssen GM. Platelet system changes associated with a training period of 18-20 months: a transverse and a longitudinal approach. Int J Sports Med 1989;10 Suppl 3:S181-5.

55. Mammen EF, Koets MH, Washington BC, et al. Hemostasis changes during cardiopulmonary bypass surgery. Semin Thromb Hemost 1985;11:281-92. 